Sains Malaysiana 46(3)(2017): 509-514

http://dx.doi.org/10.17576/jsm-2017-4603-20

\title{
Characterization of a-CN $\mathrm{C}_{\mathrm{x}}$ Thin Films Prepared by RF-PECVD Technique for Humidity Sensor \\ (Pencirian ke atas Filem Nipis a-CN ${ }_{x}$ daripada Teknik RF-PECVD sebagai Pengesan Kelembapan)
}

R. AWANG*,N.F.H AZIZ, N. PURHANUDIN \& Z. ZALITA

\begin{abstract}
In this work, amorphous carbon nitride $\left(a-C N_{x}\right)$ thin films were deposited by radio frequency (RF) plasma enhanced chemical vapor deposition (RF-PECVD) technique. The RF power and gas mixture of methane $\left(\mathrm{CH}_{4}\right)$ and nitrogen ( $\left.\mathrm{N}_{2}\right)$ flow was kept constant, while the electrode distance was varied from 1 to $6 \mathrm{~cm}$. The effect of electrode distance on the chemical bonding, morphology and humidity sensing responses of the films were investigated. Fourier transform infrared spectroscopy (FTIR) studies showed a systematic change in the spectra and showed three main peaks namely the $G$ and D-peak, $C \equiv N$ triple bonds and $C$-H/O-H groups. Uniform and porous morphology was observed for films deposited at smallest distance followed by non-porous cubicle-like grain as electrode distance increased. Subsequently formation of vertically aligned nanostructures apparent both from its surface and cross section images by increasing of electrode distance to the fullest. The humidity sensing property has been studied by recording their resistance response to relative humidity $(\mathrm{RH})$ at room temperature. It was found that the resistance value decreases from 15.4 to $3.6 \mathrm{k} \Omega$ with the increase in RH from 9 to 85\%, with the highest sensitivity of 77\% for film deposited at smallest distance of $1 \mathrm{~cm}$.
\end{abstract}

Keywords: Electrode distance; nitrile bands; resistance

\section{ABSTRAK}

Dalam penyelidikan ini, filem nipis karbon nitrida amorfus $\left(a-C N_{x}\right)$ disediakan menggunakan teknik pemendapan wap kimia secara peningkatan plasma (RF-PECVD) berfrekuensi radio (RF). Kuasa RF dan kadar aliran campuran gas yang terdiri daripada metana $\left(\mathrm{CH}_{4}\right)$ dan nitrogen $\left(\mathrm{N}_{2}\right)$ dikekalkan malar, manakala jarak elektrod diubah pada 1 hingga 6 $\mathrm{cm}$. Kesan perubahan jarak elektrod semasa proses pemendapan filem ke atas ikatan kimia, morfologi dan tindak balas pengesanan kelembapan filem dikaji. Pencirian menggunakan spektroskopi transformasi Fourier inframerah (FTIR) menunjukkan perubahan sistematik pada spektrum dan menunjukkan tiga puncak utama yang dikenali sebagai puncak $G$ dan $D$, ikatan ganda tiga $C \equiv N$ dan kumpulan $C-H / O-H$. Filem a-CN $N_{x}$ enunjukkan morfologi berongga apabila filem dimendapkan pada jarak elektrod paling hampir diikuti dengan morfologi filem tidak berliang dan butiran berbentuk kubus apabila jarak elektrod ditingkatkan. Pembentukan struktur-nano yang menegak dan sejajar amat jelas kelihatan pada kedua-dua imej daripada permukaan dan keratan rentas filem yang dimendapkan pada jarak elektrod paling jauh. Sifat pengesanan kelembapan dikaji dengan merekodkan nilai rintangan filem dalam kelembapan relatif( $R H$ ) yang berbeza pada suhu bilik. Nilai rintangan didapati berkurang daripada 15.4 kepada $3.6 \mathrm{k} \Omega$ dengan peningkatan kelembapan relatif $(\mathrm{RH}), 9$ hingga 85\%. Kepekaan terhadap kelembapan tertinggi dicapai sebanyak $77 \%$ oleh filem yang dimendap pada jarak elektrod yang terhampir iaitu $1 \mathrm{~cm}$.

Kata kunci: Ikatan nitril; jarak elektrod; rintangan

\section{INTRODUCTION}

Carbon nitride $\left(\mathrm{CN}_{\mathrm{x}}\right)$ films have excellent mechanical, chemical, optical and electrical properties that can lead to useful engineering and biomedical applications (Aono \& Nitta 2002; Schwarzer et al. 2013; Zhou et al. 2014). Previous reports claimed that carbon nitride films have bigger tendency to form an amorphous phase and amorphous carbon nitride (a-CNx) (Aziz et al. 2013a; Muhl et al. 1997; Othman et al. 2011). The $a-\mathrm{CN}_{x}$ films possess interesting properties such as low friction coefficient (Sung \& Sung 1996), electrical resistance and capacitance responses (Lee \& Lee 2004). These unique properties enable a-CN films as humidity sensing material (Lee \& Lee 2005b). Various techniques have been used to produce a-CN $\mathrm{C}_{\mathrm{x}}$ films, such as reactive sputtering (Tamura et al. 2014), laser ablation (Cappelli et al. 2011) and radio frequency plasma enhanced chemical vapour deposition (RF-PECVD) as prepared by Nur Maisarah (2013). Among these techniques, RF-PECVD has become the most widely used due to its advantage of producing uniform large area deposition, easy handling, low pinhole density, good adhesion and good step coverage (Motta \& Pereyra 2004). Desired properties of a-CN $\mathrm{CN}_{\mathrm{x}}$ thin films deposited by RF-PECVD can be obtained by varying the deposition 
parameters such as RF power, substrate temperature and deposition pressure.

Richard (2011) has prepared a set of a-CN thin films and reported that the as deposited films were observed to have a remarkable change in the chemical bonding of $\mathrm{C} \equiv \mathrm{N}$ groups and morphology at different electrode distance. These finding inspired us to study further on the applications of the films. According to Mutsukura and Akita (1999), the broad band in this region could be decomposed into five overlapping bands associated with both nitrile $(-\mathrm{C} \equiv \mathrm{N})$ and isonitrile $(-\mathrm{N} \equiv \mathrm{C})$ structures. What is most interesting, hydrogen attack can break $\mathrm{C} \equiv \mathrm{N}$ and $\mathrm{C}=\mathrm{N}$ bonds in $\mathrm{CN}_{\mathrm{x}}$ films to form $\mathrm{C}-\mathrm{H}$ and $\mathrm{N}-\mathrm{H}$ bonds. If hydrogen defects were formed intentionally and bonded weakly, then a-CN $\mathrm{CN}_{\mathrm{x}}$ can be good materials for humidity sensor (Lee \& Lee 2005a; Saha et al. 2005).

In the present work, a set of a-CN $\mathrm{CN}_{\mathrm{x}}$ thin films have been deposited using RF-PECVD technique with variation of electrode distance. The influence of electrode distance on the chemical bonding, morphology and humidity sensing responses of the films has been investigated. An interdigitated electrode has been deposited onto the $\mathrm{a}-\mathrm{CN}_{\mathrm{x}}$ thin films to study the variation of resistance response as a function of relative humidity $(\mathrm{RH})$ and time. As reported by Noor Farhana Husna (2014), simple home-built humidity set-up has been developed in our laboratory and is used for humidity measurement.

\section{MATERIALS AND METHODS}

The a-CN $\mathrm{CN}_{\mathrm{x}}$ thin films were deposited using a home-built RF-PECVD system (Kim et al. 2011) from the dissociation of pure $(99.999 \%)$ methane $\left(\mathrm{CH}_{4}\right)$ and nitrogen $\left(\mathrm{N}_{2}\right)$ gases. Both gases of $\mathrm{CH}_{4}(20 \mathrm{sccm})$ and $\mathrm{N}_{2}(47 \mathrm{sccm})$ were mixed prior to admission into the deposition chamber at a fixed flow rate. A set of a-CN $\mathrm{CN}_{\mathrm{x}}$ thin films was prepared at applied electrode distances $\left(\mathrm{d}_{\mathrm{e}}\right)$ of $1,2,3,4,5$ and $6 \mathrm{~cm}$. The films were deposited for $90 \mathrm{~min}$ and substrate temperature was kept constant at $100^{\circ} \mathrm{C}$. The as-deposited samples were characterized for chemical bonding and morphological properties using Fourier transform infra-red spectroscopy (FTIR) and field emission scanning electron microscopy (FESEM), respectively. Their thickness was measured using a FESEM's cross section images. The deposition rate was determined by dividing film thickness (nm) over the deposition time ( $\mathrm{min}$ ) of the film. The interdigitated electrodes were deposited onto the a-CN $\mathrm{CN}_{\mathrm{x}}$ thin films using RF magnetron sputtering technique to enhance the absorption and the desorption response of the samples (Aziz et al. 2013b). Finally, humidity sensing test was carried out on the prepared samples. The response of sensor to humidity or sensitivity, $\mathrm{S}$ of the samples is calculated using the (1) (Chu et al. 2013);

$$
S=\frac{R_{h}-R_{o}}{R_{o}} \times 100 \%,
$$

where $R_{h}$ refers to the resistance at certain humidity (in this work, $85 \% \mathrm{RH}$ ); and $R_{o}$ represents the original resistance of the sensors in air of $9 \% \mathrm{RH}$.

\section{RESULTS AND DISCUSSION}

Figure 1 shows the IR spectra of a-CNx thin films deposited at various electrode distances. The spectra shows the functional groups expected in $\mathrm{a}-\mathrm{CN}_{\mathrm{x}}$ thin films. For clarification, the spectra are divided into three major regions. These include: (i) the $\mathrm{sp}^{2}$ and $\mathrm{sp}^{3}$ carbon phases comprising the $\mathrm{C} \equiv \mathrm{C}$ and/or $\mathrm{C} \equiv \mathrm{N}$ which attributed to $\mathrm{D}$ peak (1350-1450 $\left.\mathrm{cm}^{-1}\right)$ and $\mathrm{G}$ peak $\left(1540-1560 \mathrm{~cm}^{-1}\right)$ and C-N bonds (Chu et al. 2013); (ii) the $\mathrm{sp}^{1}$ carbon phase associated with the $\mathrm{C} \equiv \mathrm{N}$ groups; and (iii) $\mathrm{sp}^{2}$ and $\mathrm{sp}^{3}$ phases of C-H groups and the hydroxyl N-H and/or O-H groups (Crunteanu et al. 2000; Fang et al. 2009).

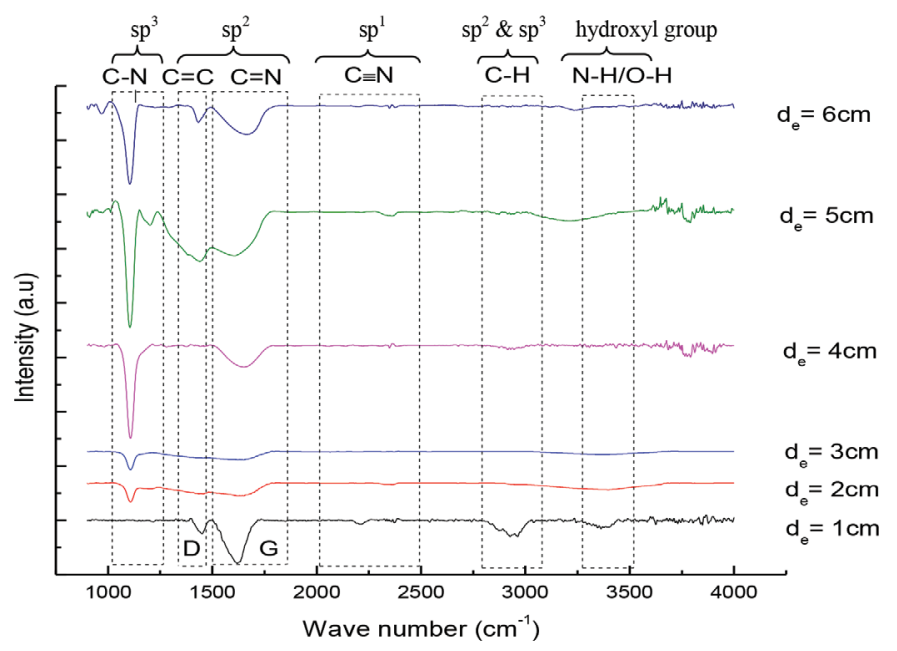

FIGURE 1. Variation of FTIR spectra as a function of wave number at different electrode distance 
Figure 1 illustrates $d_{e}=1 \mathrm{~cm}$, the sample presents a majority of $\mathrm{C} \equiv \mathrm{N}$ and $\mathrm{C} \equiv \mathrm{C}$ bonds (region (i)) with a small hump at $2200 \mathrm{~cm}^{-1}$ (region (ii)) of $\mathrm{C} \equiv \mathrm{N}$ bond. When $\mathrm{d}_{\mathrm{e}}$ is gradually increased from 2 to $3 \mathrm{~cm}$, the $\mathrm{C} \equiv \mathrm{N}, \mathrm{C} \equiv \mathrm{C}$ and $\mathrm{C} \equiv \mathrm{N}$ bonds disappeared but $\mathrm{C}-\mathrm{N}$ bond starts to appear. It can be clearly seen that the increase in the $d_{e}$ from 4 to 6 $\mathrm{cm}$ resulted in a significant increase in the IR intensity of $\mathrm{C}-\mathrm{N}$ bond with a small amount of $\mathrm{C} \equiv \mathrm{N}$ and $\mathrm{C} \equiv \mathrm{C}$ bonds . This revolution in region (i) and (ii) suggested the presence and the incorporation of nitrogen in the samples. Lowest $d_{e}$ favours the formation of $\mathrm{sp}^{1}$ and $\mathrm{sp}^{2}$ carbon phase whereas extension of $d_{e}$ induces the formation of $\mathrm{sp}^{3}$ carbon phase. Finally, it can be observed that there are peaks in region (iii) only for sample of $d_{e}=1 \mathrm{~cm}$. This result suggested the possibility of the bonds mixed with $\mathrm{N}-\mathrm{H}$ bond even the sample presents a majority of $\mathrm{C} \equiv \mathrm{N}$ and $\mathrm{C} \equiv \mathrm{C}$ bonds.

Figure 2 shows the surface morphology and crosssection images of films deposited at $d_{e}$ of 1,3 and $6 \mathrm{~cm}$. At $d_{e}=1 \mathrm{~cm}$, uniform and porous amorphous thin film is observed from its surface and cross section images. Aziz et al. (2013a) noticed by reducing the $d_{e}$ may enhance the electrode kinetics and reactions, also reflecting high conductivity. The increase in ion bombardment subsequently enhanced etching effect on the deposited films and therefore promotes porous surface. By increasing the $\mathrm{d}$ to $3 \mathrm{~cm}$, the substrate is covered with non-porous cubicle-like grain. The cross section image of the film shows the layer is made up of submicron structure which protrudes out from what appears to be an amorphous layer. Increasing the $d_{e}$ to $6 \mathrm{~cm}$ results in the formation of vertically aligned nanostructures, apparent both from its surface and cross section images. Increase in $d_{e}$ may reduce the electrode kinetics and reactions. The decrease in ion bombardment and lesser etching effect results in the growth of the amorphous layer and the formation of vertically aligned nanostructures.

The graph of deposition rate at various electrode distances is shown in Figure 3. The deposition rate is slightly decreases in the range of electrode distance 6 to $2 \mathrm{~cm}$ but drastically decreased when further reducing the electrode distance below $2 \mathrm{~cm}$. The decrease in film thickness within the electrode distance of 6 to $2 \mathrm{~cm}$ is attributed to ion bombardment on the growing surface (Nystrom et al. 2012). Further reducing the electrode
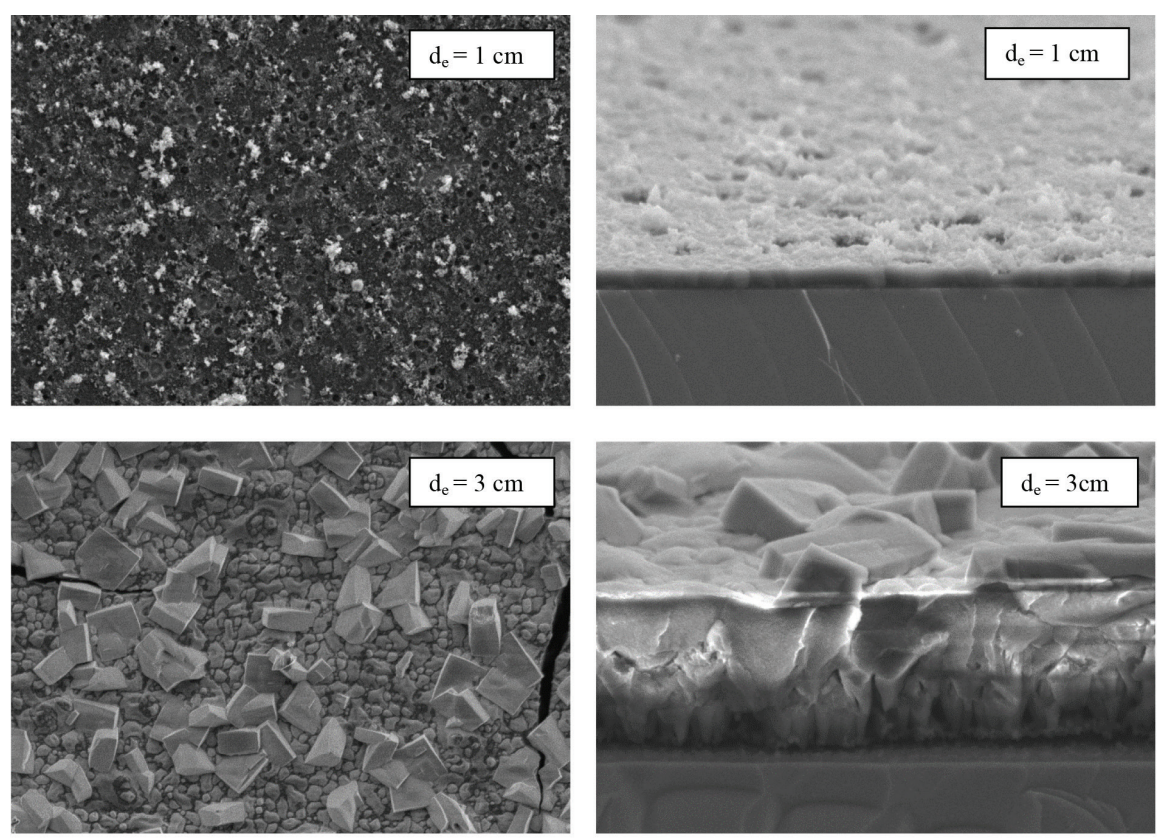

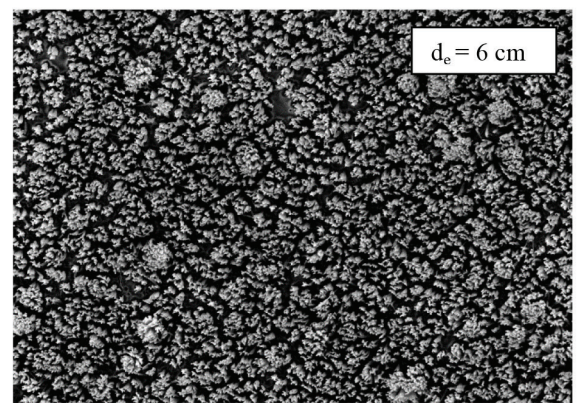

(a)

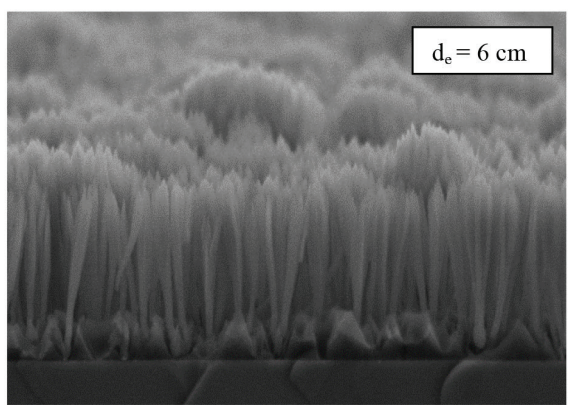

(b)

FIGURE 2. Variation of FESEM (a) surface and (b) cross section images of films deposited at electrode distance of 1,3 and $6 \mathrm{~cm}$ 


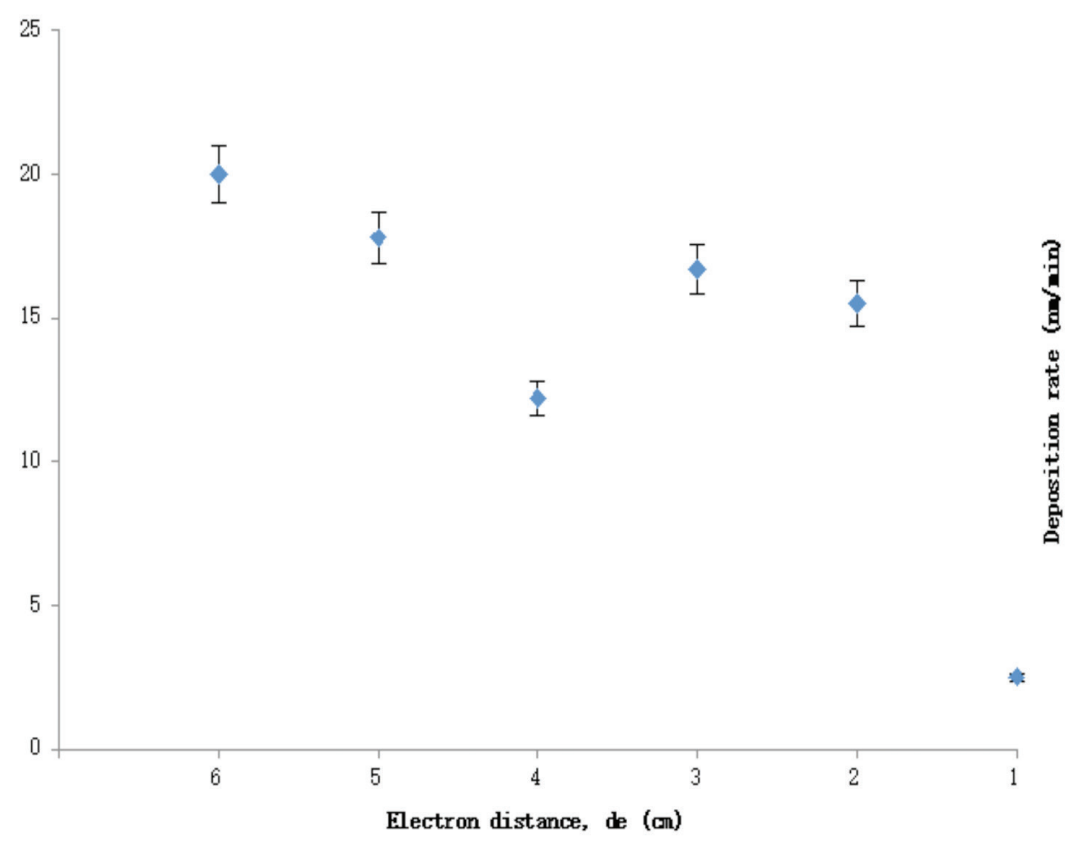

FIGURE 3. Variation of deposition rate of $\mathrm{a}-\mathrm{CN}_{\mathrm{x}}$ thin films as a function of electrode distance

distance may result in producing high electric field thus increases the ion bombardment effect. The increase in ion bombardment effect results in higher suppression on the film growth. This is pertaining to the increases of hydrocarbon bombardment effects at the growth surface which indicates to the significantly lower deposition rate of the films at $d_{e}=1 \mathrm{~cm}$.

The change in resistance of a- $\mathrm{CN}_{x}$ thin films versus time in different RH levels as a function of electrode distance is shown in Figure 4. High humidity reduces the resistivity in a way of adsorbing a conducting water layer on the film surfaces, hence the diffusion of moisture starts to take place. Dynamic response of the film is observed when the film is successively moisturized and dried as in Figure 4. It is simulated that as the diffusion of moisturizing begins, water molecules are promptly adsorbed on the film surfaces, thus contributing a current to flow and so the surface resistivity are said to be decreased. The adsorbed water molecules will rapidly desorb into surrounding once it is dried, thus reduce the film surface resistivity. Seeing that the resistivity is very sensitive to the amount of adsorbed moisture (Nystrom et al. 2012), amorphous layer of porous surface is much more reactive and absorbs more moisture than other surface structure (Bronlund \& Paterson 2004). It is found that the a-CN $\mathrm{CN}_{\mathrm{x}}$ samples show good response and repeatability to different $\mathrm{RH}$ levels. In humidity range of 9-85\% RH, the response of the samples to humidity of the a- $\mathrm{CN}_{x}$ thin films is calculated and tabulated in Table 1. The results showed that the a-CN $\mathrm{CN}_{\mathrm{x}}$ thin films deposited at $\mathrm{d}_{\mathrm{e}}=1 \mathrm{~cm}$ has the highest resistance sensitivity. As compared to other samples, this sample is the thinnest, it comprises majority of $\mathrm{C} \equiv \mathrm{N}$ and $\mathrm{C} \equiv \mathrm{C}$ bonds with highest $\mathrm{C} \equiv \mathrm{N}$ bond and has the most porous structure.

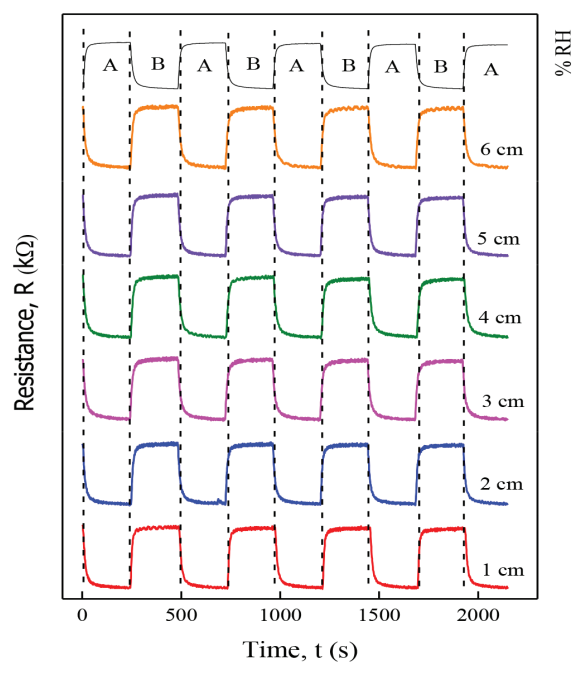

FIGURE 4. Dynamic response of the a-CN $\mathrm{N}_{\mathrm{x}}$ thin films deposited at various electrode distancento different RH levels, 9-85\%. (A-moisturizing process) and (B-drying process)

\section{CONCLUSION}

The a-CN $\mathrm{CN}_{\mathrm{x}}$ thin films were prepared by RF-PECVD technique with variation of electrode distance to study their morphology, chemical bonding and electrical properties in correlation with humidity sensing properties. The results suggested that the sensitivity of the a-CN $\mathrm{CN}_{\mathrm{x}}$ thin films as humidity sensor has the biggest influence by the presence of $\mathrm{C} \equiv \mathrm{N}$ bond and the porosity of the sample regardless the film thickness. The electronic property is concerned to structural properties of a-CN $\mathrm{CN}_{x}$ films. Therefore, $\mathrm{a}-\mathrm{CN}_{\mathrm{x}}$ thin films can be inferred to be applicant materials for humidity sensor applications. 
TABLE 1. Maximum and minimum resistance and sensitivity of a- $\mathrm{CN}_{\mathrm{x}}$ thin films as a function of electrode distance

\begin{tabular}{cccc}
\hline $\begin{array}{c}\text { Electrode } \\
\text { distance }(\mathrm{cm})\end{array}$ & $\begin{array}{c}\text { Resistance (dry), } \\
(\mathrm{k} \Omega)\end{array}$ & $\begin{array}{c}\text { Resistance (humid), } \\
(\mathrm{k} \Omega)\end{array}$ & $\begin{array}{c}\text { Sensitivity, } \mathrm{S}(\%) \\
S=\frac{R_{h}-R_{o}}{R_{o}} \times 100 \%,\end{array}$ \\
\hline 1 & 15.402 & 3.583 & 77 \\
2 & 15.615 & 8.090 & 48 \\
3 & 15.871 & 4.998 & 68 \\
4 & 16.013 & 4.720 & 71 \\
6 & 14.544 & 4.489 & 69 \\
\hline
\end{tabular}

\section{ACKNOWLEDGEMENTS}

The authors gratefully acknowledge the support in the form of a Fundamental Research Grant Scheme FRGS/1/2011/ SG/UKM/02/20 and FRGS/2/2013/SG02/UKM/02/1 by the Ministry of Higher Education, Malaysia. The authors would like to thank N. I. Azman for providing FTIR data.

\section{REFERENCES}

Aono, M. \& Nitta, S. 2002. High resistivity and low dielectric constant amorphous carbon nitride films: application to low-k materials for ULSI. Diamond and Related Materials 11(3): 1219-1222.

Aziz, N.H., Ritikos, R., Kamal, S.A.A., Hussain, N.M.\& Awang, R. 2013a. Effect of RF power and annealing on chemical bonding and morphology of a-CNx thin films as humidity sensor. Proceedings of the Universiti Kebangsaan Malaysia, Faculty of Science and Technology 2013 Postgraduate Colloquium 1571(1): 125-131. AIP Publishing.

Aziz, N.F.H., Ritikos, R., Kamal, S.A.A. \& Awang, R. 2013b. Optimizing rf power for preferential $\mathrm{C} \equiv \mathrm{N}$ bond formation in a-CNx thin films prepared by rf-PECVD technique. Journal of Physics: Conference Series 431(1): 012009.

Bronlund, J. \& Paterson, T. 2004. Moisture sorption isotherms for crystalline, amorphous and predominantly crystalline lactose powders. International Dairy Journal 14(3): 247-254.

Cappelli, E., Trucchi, D.M., Kaciulis, S., Orlando, S., Zanza, A. \& Mezzi, A. 2011. Effect of deposition temperature on chemical composition and electronic properties of amorphous carbon nitride (a-CNx) thin films grown by plasma assisted pulsed laser deposition. Thin Solid Films 519(12): 4059-4063.

Chu, J., Peng, X., Feng, P., Sheng, Y. \& Zhang, J. 2013. Study of humidity sensors based on nanostructured carbon films produced by physical vapor deposition. Sensors and Actuators B: Chemical 178: 508-513.

Crunteanu, A., Charbonnier, M., Romand, M., Vasiliu, F., Pantelica, D., Negoita, F. \& Alexandrescu, R. 2000. Synthesis and characterization of carbon nitride thin films obtained by laser induced chemical vapour deposition. Surface and Coatings Technology 125(1): 301-307.

Fang, F., Futter, J., Markwitz, A. \& Kennedy, J. 2009. UV and humidity sensing properties of $\mathrm{ZnO}$ nanorods prepared by the arc discharge method. Nanotechnology 20: 245502-1245502-7.

Kim, Y.Y., Alwi, H.A., Awang, R. \& Krishnaswamy, S. 2011. Influence of radio frequency power on thermal diffusivity of plasma enhanced chemical vapor deposition-grown hydrogenated amorphous carbon thin-films. Journal of Applied Physics 109(11): 113503.
Lee, J.G. \& Lee, S.P. 2005a. Humidity sensing properties of $\mathrm{CN} x$ film by RF magnetron sputtering system. Sensors and Actuators B: Chemical 108(1): 450-454.

Lee, J.G. \& Lee, S.P. 2005b. Surface analysis and humidity-sensing properties of carbon nitride films for microsensors. Journal of the Korean Physical Society 47: S429-S433.

Lee, J.G. \& Lee, S.P. 2004. Nano-structured carbon nitride film for humidity sensor applications. Journal Korean Physical Society 45: 619-622.

Motta, E.F. \& Pereyra, I. 2004. Amorphous hydrogenated carbonnitride films prepared by RF-PECVD in methane-nitrogen atmospheres. Journal of Non-Crystalline Solids 338: 525529.

Muhl, S., Gaona-Couto, A., Méndez, J.M., Rodil, S., Gonzalez, G., Merkulov, A. \& Asomoza, R. 1997. Production and characterisation of carbon nitride thin films produced by a graphite hollow cathode system. Thin Solid Films 308: 228-232.

Mutsukura, N. \& Akita, K.I. 1999. Deposition of hydrogenated amorphous $\mathrm{CNx}$ film in $\mathrm{CH}$ 4/N 2 RF discharge. Diamond and Related Materials 8(8): 1720-1723.

Noor Farhana Husna Abdul Aziz. 2014. Filem nipis amorfus karbon nitrida $\left(\mathrm{a}-\mathrm{CN}_{\mathrm{x}}\right)$ sebagai sensor kelembapan. MSc Thesis. Universiti Kebangsaan Malaysia, Malaysia (Unpublished).

Nur Maisarah binti Abdul Rashid. 2013. Hybrid plasma enhanced chemical vapour deposition/sputtering system for preparation of luminescent silicon carbon films. Master Thesis, University of Malaya, Malaysia (Unpublished).

Nystrom, M., Murtomaa, M. \& Salonen, J. 2012. Effect of drying pressure on pore formation of drug particles produced by electrospraying. Joint Electrostatics Conference.

Othman, M., Ritikos, R., Khanis, N.H., Rashid, N.M.A., Rahman, S.A., Ab Gani, S.M. \& Muhamad, M.R. 2011. Effects of rf power on the structural properties of carbon nitride thin films prepared by plasma enhanced chemical vapour deposition. Thin Solid Films 519(15): 4981-4986.

Richard Anak Ritikos. 2011. Fabrication and characterization of polymeric and nanostructured carbon nitride thin films: A simple difference in electrode distance. $\mathrm{PhD}$. Thesis, University of Malaya, Malaysia (Unpublished).

Saha, D., Giri, R., Mistry, K.K. \& Sengupta, K. 2005. Magnesium chromate-TiO 2 spinel tape cast thick film as humidity sensor. Sensors and Actuators B: Chemical 107(1): 323-331.

Schwarzer, A., Saplinova, T. \& Kroke, E. 2013. Tri-s-triazines (s-heptazines)-From a 'mystery molecule' to industrially relevant carbon nitride materials. Coordination Chemistry Reviews 257(13): 2032-2062. 
Sung, C.M. \& Sung, M. 1996. Carbon nitride and other speculative superhard materials. Materials Chemistry and Physics 43(1): 1-18.

Tamura, N., Aono, M., Harata, T., Kishimura, H., Kitazawa, N. \& Watanabe, Y. 2014. DC electrical conductivity study of amorphous carbon nitride films prepared by reactive RF magnetron sputtering. Japanese Journal of Applied Physics 53(2S): 02BC03.

Zhou, Y., Tang, L., Zeng, G., Chen, J., Cai, Y., Zhang, Y. \& Tang, W. 2014. Mesoporous carbon nitride based biosensor for highly sensitive and selective analysis of phenol and catechol in compost bioremediation. Biosensors and Bioelectronics 61: 519-525.
Pusat Pengajian Fizik Gunaan

Fakulti Sains dan Teknologi

Universiti Kebangsaan Malaysia,

43600 UKM Bangi, Selangor Darul Ehsan

Malaysia

*Corresponding author; email: rozida@ukm.edu.my

Received: 1 June 2013

Accepted: 1 June 2016 